Meklenborg, Lohndal \& Østby (eds) Syntax, semantics and acquisition: In honor of Hans Petter Helland, Oslo Studies in Language 12(1), 2021. 21-38. (ISSN 1890-9639/ISBN 978-82-91398-12-9)

http://www.journals.uio.no/osla

\title{
POSSESSIVE PARASITTER ELLER PARASITTISKE POSSESSIVER?
}

\author{
CATHRINE FABRICIUS HANSEN, ANNELIESE PITZ \& BERGLJOT \\ BEHRENS \\ Universitetet i Oslo
}

\section{SAMMENDRAG}

I dette bidraget drister vi oss til å forutse vanskene som innlærere med forskjellige morsmål (engelsk, tysk, og norsk) forventes å ha når de skal lære det franske possessivsystemet. Mer konkret dreier det seg om forståelse/tolking av possessivdeterminativene son, sa, ses. De tre valgte språkene har nokså ulike systemer som inviterer i forskjellig grad til transfer og tolkningsfeil, og spørsmålet er hvilke faktorer i morsmålets system som gjør det lettere eller vanskeligere å tilegne seg det franske. Det foreligger en rekke undersøkelser når det gjelder norske innlærere (se bl.a. Helland 2017; 2019), men for å kunne svare på hvilken gruppe av morsmålstalere som har den tyngste oppgaven foreslår vi en sammenlignende undersøkelse på grunnlag av en test der informantene blir bedt om å identifisere referenten for possessivet under varierende betingelser. I bidraget beskriver vi kort de forskjellige systemene, våre antagelser om innlæringsproblemer og om transfer fra de respektive L1, samt testoppsettet.

\section{[1] INNLEDNING}

Relevant forskning synes å vise at ordprosessering og syntaktisk prosessering på et fremmedspråk ikke i samme eller like tydelig omfang er utsatt for påvirkning fra morsmålet (se for eksempel Lago et al. 2020 og videre henvisninger der):

"L1 influence is clearer in L2 word processing than in syntactic processing. of course, this does not negate a potential role of L1 influence in syntactic processing: It is possible that reliable evidence will emerge once methodologically reliable comparisons are conducted. What is interesting, however, is that this variability is not observed in L2 word processing. For words, learners seem to show reliable evidence of coactivation at the form and meaning level, despite differences in L2 dominance. This suggests that CLI [Cross-Linguistic Influence] may differentially affect lexical and syntactic processing. (Lago et al. 2020, s. 9)

I vår sammenheng er fransk (FR) fremmedspråket mens hhv. norsk (NO), engelsk 
(EN) og tysk (TY) er L1. Vi kan gå ut fra at norsktalende og tysktalende som lærer fransk har [lært] engelsk som første fremmedspråk, mens fransk muligens er første (og eneste) fremmedspråk for engelsktalende FR-innlærere. Det vil si, vi har å gjøre med fransk som $\mathbf{L n}$, der $n \geq 2$.

Det spørsmål vi er opptatt av er hvordan FR-innlærere med NO, TY eller EN morsmål prosesserer - tolker, forstår - de franske possessive pekerne son, sa og ses under gitte syntaktiske betingelser.

Vanligvis behandles tolkning av 3. persons pronomener i Ln under en rent syntaktisk synsvinkel der spørsmålet er i hvilken grad Ln-innlæreren overholder de syntaktiske restriksjoner som gjelder for pronomener i det aktuelle språket og i hvilken grad han/hun eventuelt er påvirket av sitt morsmål (eller et annet Ln) under prosesseringen (se for eksempel Clahsen \& Felser 2006, Felser \& Cunnings 2012, Patterson et al. 2014 og videre henvisninger der). Leksikalsk transfer ('priming') fra L1 (eller et annet fremmedspråk) har oss bekjent ikke vært noe tema i den sammenheng. Temaet er imidlertid aktuelt også når det gjelder pronominalsystemene (i vid forstand) i nært beslektede språk der det kan være mer eller mindre klare tverrspråklige likheter mellom pronominale 'items'; jf. for eksempel NO seg v. TY sich og NO han, de vs. EN he, they.

Formålet med dette bidraget er først å klargjøre hvilke L1 faktorer som påvirker mulige feiltolkninger i tyske, norske og engelske innlæreres forståelse av franske possessiver (avsnittene 2 og 3). På dette grunlaget stiller vi opp noen hypoteser om hvilken effekt de syntaktiske betingelser for tolking av possessivene i det enkelte L1 kan ha på forståelsen (avsnitt 4). Vi skisserer et eksperiment (avsnitt 5) som inviterer den for oss unge og aktive jubilanten til å samarbeide med andre forskere innenfor det tyske, det norske og det engelske språkmiljøet, i god SPROSS-orientert ånd, siden vi, forfatterne av dette bidraget, har gått av med pensjon og ikke lenger har forskningsmidler å bidra med.

\section{[2] S-POSSESSIVER OG ANDRE POSSESSIVER: FRANSK, TYSK, NORSK, ENGELSK}

De franske $s$-possessivene son, sa og ses, i det følgende symbolisert som $s^{*}$, forutsetter en possessor - en forutgående eller eventuelt etterfølgende 'antecedent' - i singular, men er uspesifiserte mht. possessors genus/sexus. Dette vil si at både son, sa og ses i (1a) og (1b) må vise tilbake til Anna resp. Pierre; flertallsnominalene les parents 'foreldrene' og les enfants 'barna' kommer ikke på tale som antecedenter. Valget mellom de tre enhetene er bestemt av grammatisk genus og numerus til possessum - det leksikalske hodet i det nominalet som possessivet er determinativ til: son, sa og ses må forbindes med nominaler i hhv. mask. 
sing. (som dessert), fem. sing. (som crêpe) og plural (som sandwiches). ${ }^{1}$

(1)

a.

Tandis que les parents commandent du vin,

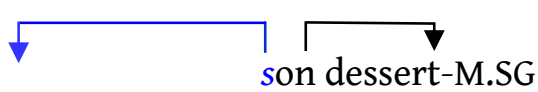

Pierre / Anna mange sa crêpe-F.SG ses sandwiches-PL

('Mens foreldrene bestiller vin, spiser Anna / Pierre desserten $\sin /$ crêpen $\sin$ / sandwichene sine')

b.

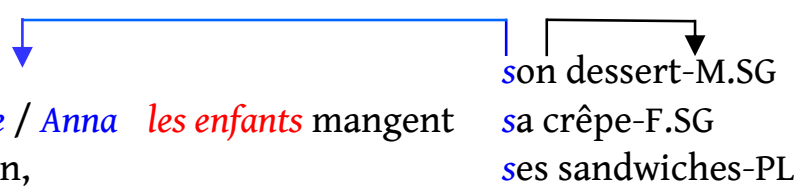

('Mens Anna / Pierre bestiller vin, spiser barna desserten hennes/ hans// crêpen hennes/ hans// sandwichene hennes/ hans')

Norsk og tysk har også adnominale s-possessiver: norsk sin, si, sitt og sine (i det følgende representert som si*) og tysk sein* (med bøyningsformene sein, seine, seinen, seinem, seiner, seines). ${ }^{2}$ I begge språkene er de forskjellige formene possessum-relaterte som for fransk son, sa, ses: De kongruerer med det nominale hodet mht. grammatisk genus og numerus, i tysk også kasus. Når det gjelder possessorrelaterte trekk er det imidlertid vesentlige forskjeller mellom $s$-possessivene i de tre språkene, eller mer generelt: mellom possessivsystemene i sin helhet (se Fabricius-Hansen et al 2017 for en oversikt).

De norske s-possessiver er inherent refleksive, dvs. sin, sitt, sine i (2) må vise til subjektet i egen setning (såkalt lokal binding, cf. Chomsky 1981 ); subjektet i den forutgående undersetningen - Linda, Andreas eller vennene - er strukturelt utelukket som antecedent/possessor. Fransk $s^{*}$ kan derimot brukes både refleksivt som i (1a) og ikke-refleksivt som i (1b). På den andre siden er norsk $s i^{*}$ uspesifisert mht. possessor-genus og -numerus - jf. (2) - mens FR $s^{*}$ som nevnt har trekket [possessor-sg.]. (I det følgende markerer vi strukturelt mulige possessorer med $\sqrt{ }$ og strukturelt utelukkede med \#, i tillegg til hhv. blå og rød

[1] Men merk at son - som mon 'min' og ton 'din' - benyttes isteden for sa (ma, ta) i kombinasjon med et feminint substantiv som begynner på en vokal, f. eks. son amie 'veninne'. I disse tilfellene kan vi si at sa bare tar formen son, dvs. at son ikke signaliserer maskulinum singular. For å si det med jubilantens ord (Helland 2006: 155): "I femininum 1p-3p finner vi to varianter av det samme morfemet avhengig av om nomenet introduseres med konsonant ( $m a, t a, s a)$ eller vokal (mon, ton, son). De siste formene sammenfaller med maskulinum 1p-3p." I det følgende ser vi bort fra denne komplikasjonen.

[2] For enkelthetens skyld ser vi bort fra den possessum-relaterte hunkjønnsformen si*. 
skrift.)

(2) Mens \#Linda/\#Andreas/\#vennene bestiller konjakk, spiser VAnna/VPetter/ $\checkmark$ barna crêpen sin/sukkertøyet sitt/ pannekakene sine.

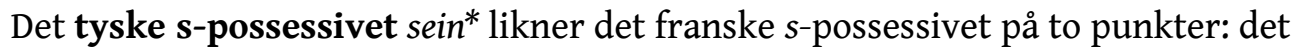
er uspesifisert for refleksivitet og spesifisert for possessor-entall. Men i motsetning til det franske $s^{*}$-possessivet, som er neutralt mht. possessors kjønn, forlanger sein* en antecedent i hankjønn, dvs. det har trekkene [possessor-sg., possessor-mask.]. ${ }^{3}$ Det betyr for eksempel at sein i (3a) kan referere (refleksivt) til det lokale subjektet Peter eller (ikke-refleksivt) til Andreas, men ikke til Anna eller Linda, mens antecedenten for son i (3b) og (3c) kan være Anna eller Pierre.

(3) a. Während \#Linda/ VAndreas Cognac bestellt, isst VPeter/ \#Anna sein Dessert.

'Mens Andreas bestiller konjakk, spiser Peter desserten sin/hans.'

b. Tandis que $\sqrt{ }$ Anna commande du cognac, VPierre mange son dessert.

'Mens Anna bestiller konjakk, spiser Pierre desserten sin/hennes.'

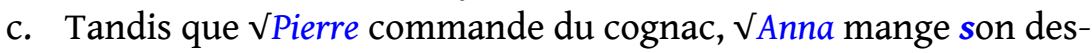
sert.

'Mens Pierre bestiller konjakk, spiser Anna desserten sin/hans,'

Forskjellene mellom s-possessivene i fransk, tysk og norsk er sammenfattet i tabell 1.

\begin{tabular}{l}
\hline Possessor-relaterte trekk \\
\begin{tabular}{|r|c|c|c|c|}
\hline & Possessiv & Numerus & $\begin{array}{l}\text { Genus } \\
\text { (hvis sg.) }\end{array}$ & Refleksivitet \\
\hline FR & son/sa/ses & sing. & - & - \\
TY & sein* & sing. & mask. & - \\
NO & sin/sitt/sine & - & - & refleksiv \\
\hline
\end{tabular}
\end{tabular}

TABELL 1. S-POSSESSIVER I FRANSK, NORSK OG TYSK

Når betingelsene for å anvende s-possessivet ikke er oppfylt, må det i alle tre språk brukes et annet possessiv(leksem):

[3] I denne artikkelen har vi utelukkende å gjøre med antecedenter/ possessor i hankjønn, hunkjønn (eller flertall). Vi ser derfor bort fra at tyske substantiver også kan være neutrum. 
- FR leur*, som er spesifisert for possessor-flertall og har formene leur (possessum-sg.) og leurs (possessum-pl.); jf. (4a).

- TY ihr*, som forlanger en antecedent i flertall eller hunkjønn entall og bøyes som sein* i samsvar med possessum; jf. (4b).

- NO hans, hennes eller deres avhengig av om possessor er hankjønn entall, hunkjønn entall eller flertall; disse possessivene er inherent irrefleksive, dvs. de kan ikke referere til subjektet i egen setning - ikke være lokalt bundet - og bøyes ikke (ytterligere). ${ }^{4}$

(4) a. Tandis que Vles parents commandent du vin, \#Anna/\#Pierre mange leur dessert/ leurs sandwiches.

'Mens foreldrene bestiller vin, spiser Anna/Pierre desserten deres/ sandwichene deres.'

b. Während VLinda Cognac bestellt, isst \#Peter ihr Eis. Während Vdie Eltern Cognac bestellen, isst \#Peter ihr Eis. 'Mens Linda/foreldrene bestiller konjakk, spiser Petter isen hennes/deres.

Engelsk har i motsetning til fransk, norsk og tysk ikke noe s-possessiv. Når det gjelder possessor-kjønn og -tall, svarer his, her og their til NO hans, hennes og deres, men i motsetning til disse er de engelske possessivene neutrale mht. refleksivitet; sml. for eksempel (5a) and (5b).

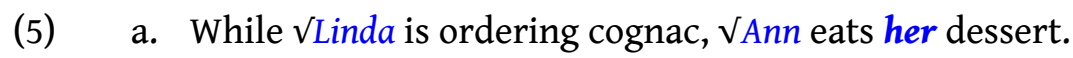

b. Mens $\sqrt{ }$ Linda bestiller konjakk, spiser \#Anna desserten hennes.

Tabell 2 gir en oversikt over possessivene uten s- i de fire aktuelle språkene.

[4] Vår fremstilling av bindings-/refleksivitetsrestriksjonen på si* er svært forenklet; se for eksempel Fabricius-Hansen et al. (2017, sek. 3) og referanser samme sted.

[5] Historisk sett dreier det seg om genitivformer av 3. persons personlige pronomener han, hun og dere. 


\begin{tabular}{|c|c|c|c|c|}
\hline \multicolumn{4}{|c|}{ Possessor-relaterte trekk } & \multirow[b]{2}{*}{ Refleksivitet } \\
\hline & Possessiv & Numerus & $\begin{array}{c}\text { Genus/Sexus } \\
\text { (hvis sing.) }\end{array}$ & \\
\hline FR & leur/leurs & plur. & - & - \\
\hline TY & $i h r^{*}$ & $\begin{array}{l}\text { sing. } \\
\text { plur. }\end{array}$ & $\begin{array}{c}\text { fem. } \\
-\end{array}$ & $\begin{array}{l}- \\
-\end{array}$ \\
\hline NO & $\begin{array}{l}\text { hans } \\
\text { hennes } \\
\text { deres }\end{array}$ & $\begin{array}{l}\text { sing. } \\
\text { sing. } \\
\text { plur. }\end{array}$ & $\begin{array}{l}\text { mask. } \\
\text { fem. } \\
-\end{array}$ & $\begin{array}{l}\text { irrefl. } \\
\text { irrefl. } \\
\text { irrefl. }\end{array}$ \\
\hline EN & $\begin{array}{l}\text { his } \\
\text { her } \\
\text { their }\end{array}$ & $\begin{array}{l}\text { sing. } \\
\text { sing. } \\
\text { plur. }\end{array}$ & $\begin{array}{l}\text { mask. } \\
\text { fem. } \\
-\end{array}$ & $\begin{array}{l}- \\
-\end{array}$ \\
\hline
\end{tabular}

TABELL 2. POSSESSIVER UTEN S- I FRANSK, TYSK, NORSK OG ENGELSK

Vi ser at de franske s-possessivene sett fra norsk- og tysktalende FR-innlæreres synspunkt er hva man kan kalle (halv-)falske venner (jf. Helland 2017): ${ }^{6}$ De likner kognatene $\mathrm{sin} /$ sitt/sine resp. sein* fonologisk/ortografisk og leksikalsk-semantisk (som uttrykk for possessivrelasjonen). Men når det gjelder morfosyntaktiske restriksjoner vedrørende possessor er det forskjeller som gjør at et Ln-FR s-possessiv under noen betingelser vil svare til et s-possessiv i L1, mens det under andre betingelser må brukes et annet possessivleksem i L1 (hans eller hennes i norsk, $i h r^{*}$ i tysk) for å få etablert den intenderte referansen. Det vil si, det foreligger leksikalsk divergens fra Ln til L1, kombinert med formell likhet mellom Ln-possessivet og det ene av de possessivene det kan svare til i L1. Dermed skulle det være duket for både positiv og negativ fonologisk/ortografisk transfer under tolkningen av Ln son/sa/ses; og siden de tyske og norske s-possessiver også innbyrdes er halv-falske venner (jf. Pitz et al. 2017), ville vi vente at slik transfer arter seg noe forskjellig for FR-innlærere med hhv. norsk og tysk morsmål.

Når det gjelder innlærere med engelsk morsmål, finner vi riktignok også leksikalsk divergens ettersom son, sa og ses alle kan motsvare his eller her, avhengig av possessors kjønn. Men det er intet formelt grunnlag for positiv eller negativ transfer. Følgelig vil vi her vente et (feil)tolkningsmønster for son, sa og ses uten den type skjevheter som halv-falske venner kan gi anledning til. Hvilke

[6] Jf. Jarvis (2009, s. 107), som definerer "false friends" som "crosslinguistic word pairs that are (1) formally the same or similar and (2) semantically similar or dissimilar (but not the same)". 
(feil)tolkningsmønstre en konkret kan forvente for hvert av de tre aktuelle LnFR/L1-parene skal vi se nærmere på i avsnitt 4. Før det er det på sin plass med noen refleksjoner om fenomenet leksikalsk transfer.

\section{[3] LEKSIKALS TRANSFER?}

Ifølge Lago et al. (2020), blant andre, er leksikalsk transfer fra Ln til L1 basert på en assosiativ relasjon mellom et Ln-ord og et semantisk og/eller fonologisk/ortografisk liknende L1-ord som utløser "coactivation" under prosesseringen. Når det gjelder teoretisk tilnærming, nevnes "the Parasitic Model" (PM) som den mest kjente:

Ln words are initially stored 'parasitically', such that their entries are associated with similar, already known words in learners' L1, L2 or Ln lexicon. These known words function as "hosts", and learners access the similarity between a host and a parasite subconsciously and on multiple levels, although initially they rely more on orthographic and phonological similarity (form level!) and only later - as their proficiency increases - on grammatical and conceptual similarity (frame and concept levels, respectively). During initial learning stages, the PM predicts pervasive CLI in processing, as hearing or reading a Ln word should activate its host(s) in other languages. When a new word is successfully learned, its form, frame, and conceptual connections are severed, such that the parasite detaches from the host and its lexical access proceeds autonomously. (Lago et al. 2020, s. 20). ${ }^{7}$

En Ln-innlærer kan naturligvis også assosiere Ln-ord med andre Ln-ord - eller evt. med ord i et annet fremmedspråk enn det aktuelle Ln.

Men hva menes i denne sammenheng med et 'ord'? Er det et leksem - en leksikalsk enhet, en stammeform eller rot - i mer eller mindre abstrakt lingvistisk forstand - eller en spesifikk bøyd form som kan være men ikke nødvendigvis er fonologisk/ortografisk identisk med stammeformen eller roten, svarende til oppslagsord i en tradisjonell ordbok (se for eksempel diskusjonene hos Lyons 1977, kap. 13, Bybee 1985 og Matthews 1991)? Og hvordan er såkalte leksemer egentlig lagret/ representert i språkbrukerens 'mentale leksikon'?

Således spørs det om FR son, sa og ses av Ln-innlæreren 'oppfattes' som selvstendige leksikalske enheter eller som (bøynings)former av et eget (possessiv)leksem (vårt $\left.s^{*}\right)$ - og hvordan dette leksemet i tilfelle er representert $\mathrm{i}$

[7] Smlg. Pavlenko (2009, s. 142): På tidlige stadier av innlæringen er L2-ord "more strongly connected to their L1 translation equivalents than to concepts [...] as proficiency increases, the links between L2 words and concepts become stronger".

[8] Mer generelt vises til Audring \& Masini (2018). Se også López (2020) for overveielser innenfor rammene av Distribuert Morfologi. 
hennes/hans 'leksikon'. Tilsvarende spørsmål melder seg når det gjelder norske morsmåltalende sitt forhold til sin, si, sitt og sine. Muligens er det sin, som tradisjonelt leksikalsk oppslagsord, snarere enn si som i tilfelle 'står for' leksemet. Tysk virker mindre problematisk på dette punktet: her kan vi nok gå ut fra at ordformen sein (mask.sg.) for morsmåltalende også representerer en stammeform/ et leksem (vårt sein*). ${ }^{9}$

I alle fall virker det rimelig å anta at tyskspråklige og norskspråklige innlærere av Ln-FR på den ene eller den andre måten assosierer son, sa, og ses med $s$ possessivene/-possessivet i morsmålet og at en slik assosiativ relasjon er særlig nærliggende når det gjelder son og sein(*) resp. son og sin, der også utlydskonsonantene svarer til hverandre. Leksikalsk transfer fra L1 under tolkningen av et Ln-FR s-possessiv i en gitt syntaktisk sammenheng innebærer da at Ln-possessivet ('parasitten') får samme interpretasjon som morsmålets s-possessiv ('verten') ville få under de samme syntaktiske betingelser. Det vil bl.a. si at L1-NO innlærere i motsetning til franske morsmålttalende vil kunne forstå son - og kanskje også sa og ses - i eksempel (2) refleksivt. Og ettersom sein(*) er markert som possessor-orientert hankjønn entall, vil en tysktalende innlærer kanskje umiddelbart relatere son i (3c) til Pierre og overse at det lokale subjektet Anna også er en mulig referent.

Ln-internt vil son/sa/ses formentlig bli assosiert med de franske possessiver for 1 . og 2. person sg. ( $\mathrm{mon} / \mathrm{ma} / \mathrm{mes}$ og ton/ta/tes). Dette vil kunne gi (ekstra) grunnlag for å oppfatte son som bestående av et leksikalsk element - en 'rot' - $s^{*}$ - som bærer av possessivsemantikken relatert til 3. persons possessor, og -on som possessum-orientert uttrykk for hankjønn entall. Som sådan er -on imidlertid spesifikk for de possessive determinativer i (possessor-)singular (mon, ton, son); den bestemte artikkelen for mask. sg. er le (jf. le dessert 'desserten'). Possessivformene $s a$ og ses svarer derimot formelt til den bestemte artikkelen i hunkjønn entall respektiv i flertall (jf. la crêpe 'crêpen', les sandwiches 'sandwichene').$^{10}$ Det er derfor også mulig at franskinnlærere assosierer sa og ses med la og les som uttrykk for fem. singular og plural, for tysk- og norsktalende sin del kanskje enda i høyere grad enn med s-possessivet i L1. Spørsmålet er imidlertid om de da nødvendigvis relaterer genus-numerus til possessum. Kan det ikke tenkes at den possessor-orienterte genus-numerus-differensieringen som er karakteristisk for de tyske possessivene sein* og ihr* (se tabell 1) og de norske irrefleksive possessivene hans, hennes og deres (se tab. 2) feilaktig overføres til son, sa, ses?

[9] Formen sein (possessum-orientert nominativ mask. sg.) faller sammen med leksemstammen (sein*), mens son og sin består av et stamme-element $\left(s^{*}\right.$ resp. $\left.s i^{*}\right)$ og en possessum-relatert markør for mask.sg., som i norsk (si-n) svarer til -n i den bestemte artikkel (den).

[10] Med denne analysen av s-on, s-a/ l-a nærmer vi oss begrepet 'root' i Distribuert Morfologi-rammeverket, som det hadde vært interessant å anvende (se f. eks. López 2020). Vi overlater imidlertid til jubilanten å ta denne utfordringen. 
I det følgende skal vi se nærmere på hvilke følger slike forskjellige L1-betingede tolkningsstrategier kan tenkes å ha for interpretasjonen av son, sa og ses under syntaktiske betingelser av den art som er eksemplifisert i (1)-(2) og (3b-c) ovenfor og mer systematisk i eksemplene (7)-(18) i tabell 3 på side 13.

[4] HVA KAN GÅ GALT - OG HVORDAN?

At en innlærer er i stand til å tolke referansen og bedømme grammatikaliteten til forekomster av FR son, sa og ses korrekt - som en morsmålstalende - viser seg ved at hun/han

- aksepterer referenter (potensielle antecedenter, possessor-kandidater) i entall uavhengig av referentens genus og uavhengig av om possessivet er lokalt bundet eller ei;

- ikke aksepterer referenter i plural;

- registrerer uoverensstemmelse i genus-numerus mellom possessiv og possessum.

Med andre ord: $s^{*}$ behandles på et eller annet kognitivt plan som bærer av possessivbetydningen for 3 . person entall og -on, $-a$, -es som possessum-relaterte 'endelser'.

Når det gjelder våre kategorier av innlærere, er det sannsynlig at de på det aktuelle stadium Ln-internt forbinder son, sa og ses med distinksjonen mellom hankjønn entall, hunkjønn entall og flertall, slik den finnes ved den bestemte artikkelen (le/la/les). jf. avsnitt 3. Vi har imidlertid pekt på to potensielle former for påvirkning fra L1 (C[ross]L[inguistic]I[nfluence]) som kan overkjøre denne koblingen og føre til mer eller mindre systematiske feiltolkninger av Ln son, sa og ses (avsnitt 3). I begge tilfeller dreier det seg om leksikalsk transfer fra L1 for så vidt som bindingsrestriksjoner og genus/numerus-trekk betraktes som en del av et ords eller en ordforms syntaktisk-semantiske egenskaper.

Den ene muligheten (CLI-A) er at genus-numerus-trekkene oppfattes som possessor-i stedet for possessum-orienterte under påvirkning fra L1, der possessor-orientering er enerådende eller klart dominerende (jf. avsnitt 2). ${ }^{11}$ Med andre ord: son, sa og ses assosieres med og tolkes feilaktig som visende til en possessor i hhv. hankjønn entall, hunkjønn entall og flertall, som tilfellet er med his, her, their i L1-EN, de irrefleksive possessivene hans, hennes, deres i L1-NO og sein* (mask. sg.), ihr* (fem.sg. og plur.) i L1-TY. ${ }^{12}$ En slik 'bakutrettet' omorientering

[11] For L1 norsk vises til Hellands (2017, s. 92) H[ypothesis] 5: "Norwegian learners of French relate the possessive to the possessor rather than to the possessum."

[12] Hva angår ses, forutsetter en slik omorientering vel at det korrekte FR leksem for possessor-plural, leur* (se avsnitt 2, tabell 2) ikke er helt 'present' for innlæreren. Se Helland (2017, avsnitt 3.2) for relevante feil i oversettelse eller grammatikalitetsbedømmelse. 
mot possessor er særlig nærliggende når possessum ikke har noe å si for valget av possessiv i L1, som tilfellet er i engelsk. Når det gjelder tysk, markerer de possessum-orienterte bøyningsformene til sein ${ }^{*} /$ ihr $^{*}$ og andre determinativer (se avsnitt 2) ikke possessum-genus og numerus så entydig som tilfellet er med franske determinativer; dvs. koblingen mellom possessivform og possessums genus/numerus er neppe så sterk som i fransk. ${ }^{13} \mathrm{Og}$ i norsk er possessum-relatert bøyning begrenset til det refleksive possessum $s i^{*}(s i-n, s i-t t, s i-n e)$, som er uspesifisert mht. possessor-kjønn og -tall. Både for norskspråklige og tyskspråklige innlærere av Ln-FR kan innflytelse fra engelsk som L2 medvirke til CLI-A.

Den andre muligheten (CLI-B) er bare aktuell i relasjon til norsk og tysk L1 og består $\mathrm{i}$ at possessor-relaterte restriksjoner som kjennetegner morsmålets $s$ possessiv(er) overføres til s-possessivene i Ln. Som nevnt tidligere, er en slik fonologisk/ortografisk utløst transfer særlig nærliggende når det gjelder son i relasjon til possessivstammen sein* $\mathrm{i}$ tysk og possessivformen sin i norsk. ${ }^{14}$

For innlærere med norsk L1 betyr CLI-B at son vil bli tolket refleksivt slik at egnede ikke-lokale possessor-kandidater i entall som Anna i (3b) og Pierre i (3c) ovenfor blir oversett. Om den refleksive tolkningen slår inn uavhengig av om det lokale subjektet er hankjønn entall som Pierre i (3b) eller hunkjønn entall som Anna i (3c) er kanskje mer åpent - og vel i alle fall mest sannsynlig dersom det franske possessum, som dessert 'dessert' i (3b) og (3c), motsvarer et hankjønns/felleskjønnssubstantiv i norsk, slik at son tolket refleksivt ville bli oversatt med den halv-falske vennen sin. Når det gjelder sa og ses er det som nevnt i avsnitt 3 ikke så tydelig fonologisk/ortografisk grunnlag for leksikalsk transfer fra s-possessivet i L1 som i tilfellet son. Norske innlærere kan imidlertid tenkes å kombinere CLI-B og CLI-A. I så fall vil son, sa og ses tolkes refleksivt og samtidig som spesifisert for possessor-genus/numerus. Det vil si at $s^{*} \mathrm{i}$ de franske possessivene parasittisk hekter seg på norsk si* som bærer både av 'possessiv-betydningen' for 3. person og en refleksivitetsrestriksjon mens genus/numerus-trekkene som uttrykkes av -on, - $a$ og -es kobles til possessor i stedet for possessum.

For innlærere med tysk L1 vil CLI-B ha samme effekt som CLI-A når det gjelder son, som vil bli tolket som possessor-relatert hankjønn entall i likhet med den halv-falske vennen $\operatorname{sein}(*)$. Innlæreren vil da f. eks. overse at son kan vise til Anna i (3b) og (3c). Det virker imidlertid lite sannsynlig at tyske innlærere asso-

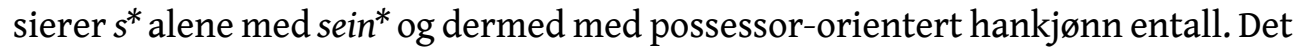
ville utelukke også sa og ses fra å bli tolket til referenter i hunkjønn entall. CLIA, som fører til at sa og ses tolkes som ihr*, er således nok en mer plausibel kilde

[13] Men se Patil \& Lago (2020) for eksperimenter som viser at possessor-relaterte og possessum-relaterte restriksjoner kan interagere under prosesseringen.

[14] For L1 norsk vises til Hellands (2017, s. 87) H[ypothesis] 4: "Norwegian learners of French generalize the transfer of $s i^{*}$ to $s^{*}$ in their L2 grammar." 
til feiltolkninger av sa og ses enn CLI-B.

CLI-A innebærer at innlæreren under tolkningen orienterer seg mot possessor og ikke hefter seg ved genus-numerus-samsvaret mellom possessiv og possessum, enten det skyldes manglende forståelse for samsvar, ufullstendig beherskelse av franske substantivers genus og bøyning eller sviktende oppmerksomhet under prosesseringen. Hva angår CLI-B kan norske innlærere imidlertid prinsipielt sett tenkes å tolke FR $s^{*}$ som refleksivt i likhet med $s i^{*}$ i L1 og samtidig ha en korrekt forståelse av at 'endelsene' -on, - $a$ og -es er possessum-relaterte (kongruensbestemte).

Når det gjelder FR-innlærere med L1-NO stemmer våre antakelser om CLI-A og CLI-B overens med hypoteser som jubilanten har formulert og overprøvd ved hjelp av oversettelses- og cloze-tests samt grammatikalitetsvurdering (se bl.a. Helland 2017, 2019). Nedenfor skal vi skissere hvordan forskjeller mellom norsktalende, tysktalende og engelsktalende franskinnlærere sine tolkninger av franske s-possessiver eventuelt kan påvises eksperimentelt.

\section{[5] EKsPERIMENTET - EN ABC ${ }^{15}$}

For å teste de hypotesene vi har kommet frem til, tenker vi oss et lese-eksperiment (self-paced reading) der de såkalte critical items, som vi skal kalle kjernesetninger/-eksempler, varierer systematisk etter mønsteret til de tolv eksemplene i tabell 3. For hvert av de tre possessivene son, sa og ses er det her et sett med fire komplekse setninger. Hver setning består av en foranstilt adverbiell bisetning med tandis que 'mens' og en etterfølgende hovedsetning der possessivet opptrer som del av et nominalt objekt. I hvert sett med fire slike eksempler er det:

- to eksempler der de lokale subjektene er hhv. hunkjønn (Anna) og hankjønn (Pierre) entall mens de ikke-lokale er flertall (les parents), og possessivet følgelig må referere til det lokale subjekt (refleksiv bruk);

- to eksempler der det omvendt er de ikke-lokale subjekter som er entall (hhv. hunkjønn og hankjønn) men de lokale subjekter er flertall (les enfants), slik at possessivet må vise tilbake til det ikke-lokale (bisetnings-)subjekt (ikke-refleksiv bruk).

Etter at testpersonene har blitt presentert og har lest en setning får de et spørsmål med tre svarmuligheter (på fransk). Svaret vil vise om de har forstått referansen til possessivet korrekt. Når de får og besvarer spørsmålet, ser de ikke lenger setningen. For eksempel vil visningen av (6a), som svarer til (7) i tabell 3, etterfølges av spørsmålet (6b) med svarmulighetene i (6c).

\footnotetext{
${ }^{15} \mathrm{~A}[$ nneliese], $\mathrm{B}[\operatorname{ergljot}], \mathrm{C}$ [athrine] - med takk til Torgrim Solstad for nyttige innspill.
} 
(6) a. Tandis que les parents commandent du cognac, Anna mange son dessert. ('Mens foreldrene bestiller vin, spiser Anna desserten sin.')

b. A qui appartient le dessert?

('Hvem tilhører desserten?' 'Hvem sin dessert er det?')
c. Lesparents Anna Quelqu'und'autre 'Foreldrene' 'En annen'

Siden det forventes at informantene vil ha en rekke korrekte tolkninger, mer eller mindre velfunderte, og siden de forventes å ha delvis overlappende feiltolkninger til tross for de ulike systemene i deres L1, vil det være nødvendig med minst 5 sett kjerneeksempler svarende til tabell 3, dvs. i alt 60 kjerneeksempler, for at man skal kunne spore feilene til transfer fra L1.

Merk at i det endelige oppsettet skal subjunksjonen varieres: pendant que 'mens', parce que 'fordi', comme 'siden', puisque 'siden'.

I et slikt oppsett må testpersoner med fransk morsmål forventes å tolke alle tre possessiver som refererende til entallssubjektet, uansett om det er han- eller hunkjønn og uansett om det befinner seg i bisetningen eller hovedsetningen: Anna i (7), (9), (11), (13), (15), (17) og Pierre i (8), (10), (12), (14), (16) og (18); flerstallsnominalene les parents og les enfants er grammatisk utelukkede som possessorer. 


\begin{tabular}{|c|c|c|c|c|c|cc|}
\hline \multicolumn{9}{c}{$\begin{array}{c}\text { Ikke- } \\
\text { lokalt } \\
\text { subjekt }\end{array}$} & Verbal & $\begin{array}{c}\text { Lokalt } \\
\text { subjekt }\end{array}$ & Verbal & $\begin{array}{c}\text { Posses- } \\
\text { siv }\end{array}$ & $\begin{array}{c}\text { Posses- } \\
\text { sum }\end{array}$ \\
\hline $\mathbf{( 7 )}$ & $\begin{array}{c}\text { Tandis } \\
\text { que }\end{array}$ & $\begin{array}{c}\text { les } \\
\text { parents }\end{array}$ & $\begin{array}{c}\text { commandent } \\
\text { du cognac }\end{array}$ & Anna & mange & son & dessert \\
\hline $\mathbf{( 8 )}$ & $\begin{array}{c}\text { Tandis } \\
\text { que }\end{array}$ & $\begin{array}{c}\text { les } \\
\text { parents }\end{array}$ & $\begin{array}{c}\text { commandent } \\
\text { du cognac }\end{array}$ & Pierre & mange & son & dessert \\
\hline $\mathbf{( 9 )}$ & $\begin{array}{c}\text { Tandis } \\
\text { que }\end{array}$ & Anna & $\begin{array}{c}\text { commandent } \\
\text { du cognac }\end{array}$ & $\begin{array}{c}\text { les } \\
\text { enfants }\end{array}$ & mangent & son & dessert \\
\hline $\mathbf{( 1 0 )}$ & $\begin{array}{c}\text { Tandis } \\
\text { que }\end{array}$ & Pierre & $\begin{array}{c}\text { commandent } \\
\text { du cognac }\end{array}$ & $\begin{array}{c}\text { les } \\
\text { enfants }\end{array}$ & mangent & son & dessert \\
\hline
\end{tabular}

\begin{tabular}{|c|c|c|c|c|c|ll|}
\hline (11) & $\begin{array}{c}\text { Tandis } \\
\text { que }\end{array}$ & $\begin{array}{c}\text { les } \\
\text { parents }\end{array}$ & $\begin{array}{c}\text { commandent } \\
\text { du cognac }\end{array}$ & Anna & mange & sa & crêpe \\
\hline $\mathbf{( 1 2 )}$ & $\begin{array}{c}\text { Tandis } \\
\text { que }\end{array}$ & $\begin{array}{c}\text { les } \\
\text { parents }\end{array}$ & $\begin{array}{c}\text { commandent } \\
\text { du cognac }\end{array}$ & Pierre & mange & sa & crêpe \\
\hline $\mathbf{( 1 3 )}$ & $\begin{array}{c}\text { Tandis } \\
\text { que }\end{array}$ & Anna & $\begin{array}{c}\text { commandent } \\
\text { du cognac }\end{array}$ & $\begin{array}{c}\text { les } \\
\text { enfants }\end{array}$ & mangent & $s a$ & crêpe \\
\hline $\mathbf{( 1 4 )}$ & $\begin{array}{c}\text { Tandis } \\
\text { que }\end{array}$ & Pierre & $\begin{array}{c}\text { commandent } \\
\text { du cognac }\end{array}$ & $\begin{array}{c}\text { les } \\
\text { enfants }\end{array}$ & mangent & $s a$ & crêpe \\
\hline
\end{tabular}

\begin{tabular}{|c|c|c|c|c|c||ll|}
\hline (15) & $\begin{array}{c}\text { Tandis } \\
\text { que }\end{array}$ & $\begin{array}{c}\text { les } \\
\text { parents }\end{array}$ & $\begin{array}{c}\text { commandent } \\
\text { du cognac }\end{array}$ & Anna & mange & ses & sandwiches \\
\hline $\mathbf{( 1 6 )}$ & $\begin{array}{c}\text { Tandis } \\
\text { que }\end{array}$ & $\begin{array}{c}\text { les } \\
\text { parents }\end{array}$ & $\begin{array}{c}\text { commandent } \\
\text { du cognac }\end{array}$ & Pierre & mange & ses & sandwiches \\
\hline $\mathbf{( 1 7 )}$ & $\begin{array}{c}\text { Tandis } \\
\text { que }\end{array}$ & Anna & $\begin{array}{c}\text { commandent } \\
\text { du cognac }\end{array}$ & $\begin{array}{c}\text { les } \\
\text { enfants }\end{array}$ & mangent & ses & sandwiches \\
\hline $\mathbf{( 1 8 )}$ & $\begin{array}{c}\text { Tandis } \\
\text { que }\end{array}$ & Pierre & $\begin{array}{c}\text { commandent } \\
\text { du cognac }\end{array}$ & $\begin{array}{c}\text { les } \\
\text { enfants }\end{array}$ & mangent & ses & sandwiches \\
\hline
\end{tabular}

TABELL 3. OPPSETT FOR KJERNESETNINGER/-EKSEMPLER

Når det gjelder våre tre kategorier av franskinnlærere kan våre forventninger sammenfattes som følger:

Testpersoner med tysk L1 vil gjennomgående korrekt tolke son som sein*, dvs. som visende til referenten i hankjønn entall (Pierre) uavhengig av om det dreier seg om det lokale subjekt, som i (8), eller ikke, som i (10). Men de vil sannsynligvis ha en tendens til å overse egnede referenter for son i hunkjønn entall slik at de ikke finner noen possessor (svaralternativ Quelqu'un d'autre) i tilfeller 
som (7) og (9). Når det gjelder sa forventes testpersonene tilsvarende korrekt å foretrekke kandidaten i hunkjønn entall (Anna) under betingelser som (11) og (13) og være mer usikre når en slik ikke er tilgjengelig, som i (12) og (14). Hva angår ses forventer vi at informantene ikke helt sjeldent feilaktig oppfatter den ikke-egnede flertallskandidaten - les parents resp. les enfants i våre eksempler som possessor, kanskje ikke minst når det dreier seg om det lokale subjektet, som i (17) og (18). ${ }^{16}$ På den andre siden kan likheten mellom ses og sein* tenkes å føre til en viss preferanse for å oppfatte ses som visende til hankjønn (Pierre) fremfor hunkjønn (Anna) entall.

Testpersoner med norsk $\mathbf{L 1}$ forventes å foretrekke en refleksiv tolkning av son, særlig når det lokale subjektet er hankjønn entall som i (8) (Pierre), men til dels også når det dreier seg om hunkjønn entall som i (7) (Anna) eller flertall som i (9)-(10) (les enfants); i sistnevnte tilfelle er tolkningen feilaktig. Når det gjelder $\boldsymbol{s} \boldsymbol{a}$ vil informantene muligens foretrekke en hunkjønnsreferent (Anna) både som lokalt (11) og som ikke-lokalt (13) subjekt, men ellers fortrinnsvis velge den refleksive tolkningen også når den er grammatisk utelukket, som i (14), eller eventuelt avvise begge 'kandidater'. For ses venter vi en tilsvarende fordeling av (ukorrekte) flertallstolkninger - spesielt når flertallskandidaten er lokalt subjekt som i (17)-(18) (les enfants) -, korrekte refleksive entallstolkninger (Anna resp. Pierre) og avvisning av begge possessor-kandidatene.

Som nevnt $i$ avsnitt 4 , antar vi at testpersoner med engelsk $\mathbf{L} 1$ har en tendens til å tolke son, sa og ses som hhv. his, her og their. I relasjon til våre kjernesetninger vil deres tolkningsmønstre da ikke atskille seg vesentlig fra det vi forventer for innlærere med tysk L1 (se ovenfor). Men muligens er feiltolkninger av ses som visende til flertallsreferenten i tilfeller som (15)-(18) mindre hyppige enn for innlærere med L1 tysk, som kan tenkes å assosiere både sa og ses med ihr* - og som dessuten kan bli påvirket av likheten mellom sa/ses og sein*.

Som såkalte fillers/distractors - avledere - tenker vi oss setninger med andre pronominale enheter enn possessivene, men hvor spørsmålsoppsettet kan være den samme som for kjerne-eksemplene. Avlederne bygges etter samme mønster som kjernesetningene, om enn rekkefølgen på leddsetningene kan skifte, og antall avledere skal helst være minst like stort som antallet kjernesetninger. Spørsmålene knyttet til avlederne trenger ikke se helt like ut. Vi foreslår noen i eksemplene (19a-d) nedenfor. Kjernesetninger og avledere randomiseres i det ferdige oppsettet, og rekkefølgen av de 'positive' svaralternativene varieres.

\section{a. Parce que Pierre a oublié l'anniversaire de Marianne, il lui envoie un gros}

[16] Det kan også tenkes at ses oppfattes som refererende summativt til kombinasjonen av subjektet $\mathrm{i}$ hovedog subjektet i bisetningen - en mulighet som våre svaralternativer ikke tar høyde for. 
bouquet de fleurs.

'Siden Pierre har glemt Mariannes bursdag, sender han (henne) en stor bukett blomster'.

Qui reçoit des fleurs?

'Hvem får blomster?'

Pierre Marianne Quelqu'und'autre 'En annen'

b. Le professeur envoie une bouteille de vin à la collègue qui vient de s'installer dans le bureau à côté.

'Professoren sender en flaske vin til en kollega som nettopp har flyttet inn på kontoret ved siden av.

Qui a déménagé? ('Hvem har flyttet?')

Le professeur La collègue Tousles deux ('Begge to')

c. Marianne accompagne Pierre à la boutique et elle lui conseille d'acheter le manteau le plus cher.

'Marianne følger Pierre til butikken og råder ham til å kjøpe den dyreste frakken.

Qui achète le manteau le plus cher?

Hvem kjøper den dyreste frakken?

Pierre Marianne Les deux

'Begge to'

d. Le professeur et un collègue envoient une bouteille de champagne à Pierre, parce qu'il les a aidés à déménager.

'Professoren og en kollega sender en flaske champagne til Pierre fordi han har hjulpet dem med å flytte.'

Qui a aidéle professeur?

'Hvem har hjulpet professoren?'

Un collègue

Le professeur

Quelqu'un d'autre

'En annen'

Det skal til slutt understrekes at vårt oppsett for kjernesetninger ikke omfatter variasjoner av typen (20a-d), der den ikke-lokale og den lokale possessor-kandidaten er hhv. hunkjønn og hankjønn entall, eller omvendt, og possessivet følgelig er referensielt tvetydig. 
(20) a. Tandis que $\sqrt{ }$ Anna commande du cognac, VPierre mange son dessert.

b. Tandis que VPierre commande du cognac, VAnna mange son dessert.

c. Tandis que $\sqrt{ }$ Anna commande du cognac, VPierre mange sa crêpe.

d. Tandis que $\sqrt{ }$ Pierre commande du cognac, VAnna mange sa crêpe.

e. Tandis que $\sqrt{ }$ Anna commande du vin, VPierre mange ses sandwiches.

f. Tandis que $\sqrt{ }$ Pierre commande du vin, $\sqrt{ }$ Anna mange ses sandwiches.

Det er mulig at eventuelle forskjeller mellom tolkningsmønstre til de tre informantgrupper ville komme tydeligere frem dersom slike eksempler ble tatt med i eksperimentet. Men det samlede antall testsetninger ville bli for omfattende. Et tema for et oppfølgende eksperiment?

\section{[6] AVSLUTNING}

I dette arbeidet har vi utbokstavert hvilke tolkningsproblemer innlærere av fransk er forventet å ha når de leser, og vi har formulert spesifikke hypoteser om hvilke forskjeller vi kan forvente, om innlærerne har norsk, tysk eller engelsk som morsmål. Med noen fantasifulle tilleggseksempler fra jubilanten selv eller noen av hans fremtidige assistenter skulle testen være klar til å settes opp med instrukser til testpersonene om å lese hver setning i eget tempo, trykke seg videre til spørsmålet, og med noen innledende øvelser (tre helt andre typer setninger og spørsmål) være klare til å trykke en av tre oppgitte tall- eller bokstavtaster - som bør være like lette å nå, men ikke ligge altfor tett på hverandre for å avgi sine svar. Håpet er at svarene virkelig kan fortelle oss om våre forventninger om L1-transfer holder.

Lykke til, notre cher collègue Jean Pierre, med jubileet og med testen! Vi gleder oss til å lese sluttresultatet, om så på fransk!

\section{REFERANSER}

Audring, Jenny \& Francesca Masini (eds.). 2018. The Oxford Handbook of Morphological Theory. Oxford: Oxford University Press.

Bybee, Joan L. 1985. Morphology. A Study of the Relation between Meaning and Form. Amsterdam: Benjamins.

Chomsky, Noam. 1981. Lectures of Government and Binding. Dordrecht: Foris.

Clahsen, Harald \& Claudia Felser. 2006a. How native-like is non-native language processing?. Trends in cognitive sciences 10(12). 564-570.

Fabricius-Hansen, Cathrine, Hans Petter Helland, \& Anneliese Pitz. 2017. An L2 perspective on possessives: Contrasts and their possible consequences. Oslo 
Studies in Language (OSLa) 9(2). 3-39.

Felser, Claudia \& Ian Cunnings. 2012. Processing reflexives in a second language: The timing of structural and discourse-level constraints. Applied Psycholinguistics 33(3). 571-603.

Helland, Hans Petter. 2006. Ny fransk grammatikk. Oslo: Universitetsforlaget.

Helland, Hans Petter. 2017. An empirical L2 perspective on possessives: French/Norwegian. Oslo Studies in Language (OSLa) 9(2). 75-104.

Helland, Hans Petter. 2019. La notion de transfert appliquée au francais comme langue étrangère. Bergen Language and Linguistics Studies (BeLLS) 10(1).

Jarvis, Scott. 2009. Lexical transfer. In Aneta Pavlenko (ed.), The bilingual mental lexicon: Interdisciplinary approaches, 99-124. Bristol: Multilingual matters.

Lago, Sol, Michela Mosca \& Anna Stutter Garcia. 2020. The Role of Crosslinguistic Influence in Multilingual Processing: Lexicon versus Syntax. Language Learning 71. 1-30. DOI: 10.1111/lang.12412.

López, Luis. 2020. Bilingual Grammar. Toward an Integrated Model. Cambridge: Cambridge University Press.

Lyons, John. 1977. Semantics. Vol. 2. Cambridge: Cambridge University Press.

Matthews, Peter H. 1991. Morphology: An introduction to the theory of word structrure. 2nd edition. Cambridge: Cambridge University Press

Patil, Umesh \& Sol Lago. 2020. How antecedent retrieval influences prediction: a cue-based retrieval model. AMLaP 2020. Poster: 241.

Patterson, Clara, Helena Trompelt \& Claudia Felser. 2014. The online application of binding condition B in native and non-native pronoun resolution. Frontiers in psychology 5.

Pavlenko, Aneta. 2009. Conceptual Representation in the Bilingual Lexicon and Second Language Vocabulary Learning. In Aneta Pavlenko (ed.), The bilingual mental lexicon: Interdisciplinary approaches, 125-160. Bristol: Multilingual matters.

Pitz, Anneliese, Oliver Bott, Torgrim Solstad, Bergljot Behrens \& Cathrine Fabricius-Hansen. 2017. An empirical perspective on possessives: German/Norwegian. Oslo Studies in Language (OSLa) 9(2). 43-74. 
KONTAKT

Cathrine Fabricius Hansen

UiO

c.f.hansen@ilos.uio.no

Anneliese Pitz

UiO

a.p.pitz@ilos.uio.no

Bergljot Behrens

UiO

bergljot.behrens@ilos.uio.no 